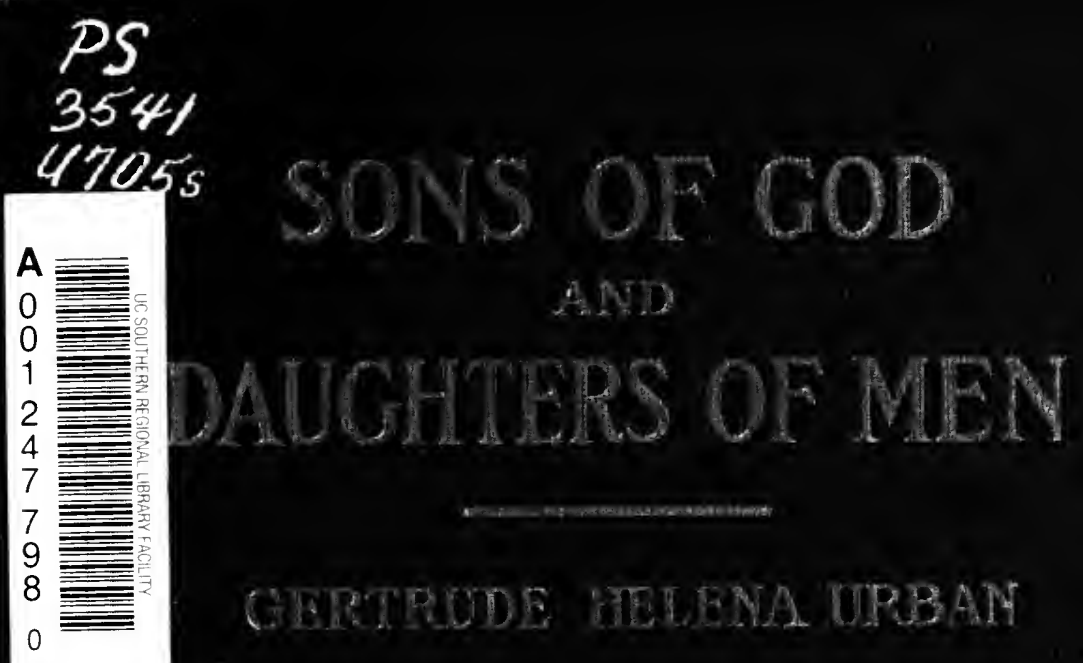

California gional icility 


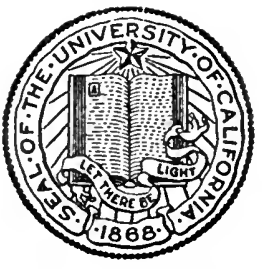

THE LIBRARY

OF

THE UNIVERSITY

OF CALIFORNIA

LOS ANGELES 




\title{
SONS OF GOD AND DAUGHTERS OF MEN
}

\author{
BY \\ GERTRUDE HELENA URBAN
}

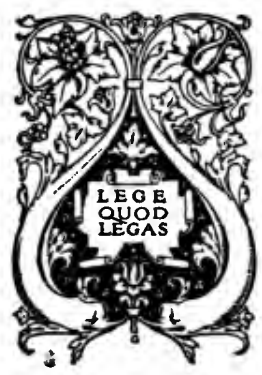

BOSTON

SHERMAN, FRENCH \& COMPANY 1912 
Copyright, 1912

Sherman, French \& Company 


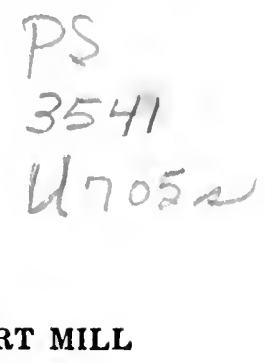

God knows we honour thee that from high rank Didst stoop to theme held poor for sage or seer; With valiant tome to hallow lowlier sphere In consecration, just, and stern, and frank ! Sad sage, that from the cup of quiet drank Sad serious sage, our onliest friend-nay here We greet all friends that proffered us good cheer, And in thy name we give to all our thank! God knows we honour thee and hold thee dear, And in the whirling world that spurns the dead, And in the operose life that must forget, Sometimes a quiet hour comes when yet We know, for all the cypress waving o'er thy bed, Thy grave is in our hearts, and thou art near. 

The subjection of woman has involved the maternalizing of the male. Under its bonds he has been forced into new functions, impossible to male energy alone. He has learned to love and care for someone besides himself. He has had to learn to work, to serve, to be human. It should not be considered as an extreme maternal sacrifice, but as a novel and thorough system of paternal sacrifice-the male of genus homo coerced into the expression of maternal energy . . . Races there were and are which reproduce themselves without the masculine organism by hermaphroditism and parthenogenesis. But it has been proven better for the race to have two highly developed parents rather than one. The elevation of the male to full racial equality has involved her temporary subjection. Now that the world is no longer benefited by her subordination, she is coming steadily out into direct personal expression, into the joy of racial action in full freedom.

Charlotte Perkins Stetson. 



\section{FOREWORD}

As this book of verse, the result of a youthful impulse acted upon without disciplined formulation, is offered the public in my maturity, I off er with it some apologies, not for the content or tone, but for the presentation. Development and wider reading have since taught me much, but not, as yet, the restraint to forego an unauthorized theme and purpose, the control of the sonnet form, nor creative visualizing and the manipulation of the concrete symbol. One hope remains, however, that the passionate sincerity of youth, with some of its fire and spontaneity (if these are not as foreign to the sonnet as is didacticism to verse in general) may be ameliorating, though never redeeming, features.

As to the declaration of faith and its emotional aspects, maturity has brought no change. Darwin and Spencer, among others in the nineteenth century, have furthered the ancient theory of woman's inferiority; Wolff wrote to reveal her "anatomical beastiality"; and Weininger, in the twentieth, claims proof that woman and prostitute are one and the same, with the mother, as a phenomenon, the lowest form. Added to the general concept of inferiority, and the special world-view that woman is not an end in herself, but merely the means to an end: the race (unlike man, who is both means and end) is the uninterested, complacent, or enthusiastic acceptance of these views by woman's "natural protectors," and the difficulties, negative or other, they have placed in the way of her eff orts to cope with them.

It is clear that these verses are not concerned, 
save indirectly, with the matter of legal recognition of equality for the sexes. As that involved, issue, however, is now before the world of men, still reluctant and without faith, these belated verses may yet be opportune. And as the indifference and opposition of men (infinitely considerate of the physical needs of women) to woman as an egoity, will be as disappointing after the state grants her citizenship, as before that long fought for recognition, I am ready, if necessary, to sell my soul as an artist, and to take a humbler rank as a sign of the times.

G. H. U. 
PART I 

IF one should read the page where $I$ inlay

A word for those of us, that differing, stood For what to us is beautiful and good,

I doubt not he will waive the sheet, and say:

"Here spoke a woman in unlovely way;

Her lip not moulded into plenitude

A tender music, as with woman should;

Her tongue it is not sweet, nor me may sway."

Go read where you my languishings lament

And tell me that no purpose mine to fill

The lips with silent, or with told, dissent.

"She pleases not, unsmiling thus to go;

And none content," you say, "could speak thus ill."

And I: "Even so, my friend, even so, even so." 


\section{II}

Have patience, Mother, though thy children fail

In thy large calm, and teach us even how

Even thine own feet found but one step enow

So that they bore thee through thy chosen vale.

We know that to the last we shall assail

Thy law and speak the idle, hollow vow

To walk without thee, while against thy brow

We lay the face life darkened, death made pale.

Teach us, $\mathbf{O}$ Mother, thy serenity,

That brought us forth in tranquil faith, with smile.

Though cold we turn away from thy decree,

In humble love thou holdest each the while.

So let thy children come again to thee

Impartial Mother; thou shalt reconcile. 


\section{III}

Hear us, thy children, that doubt-driven come From our Gehenna to thy willing knee;

We know thy lap hath room for such as we, That thy broad bosom hath solatium.

If be the grave the soul's mausoleum,

Or lesser secret we should ask of thee,

If, or if not, beyond the tomb we be,

Quick wake the soul that slumbers yet all dumb;

Turn our eyes inward; still the self-demand; Thy one great passion let us with thee share And love the seed of truth that from thy hand Silvern and silent falleth everywhere;

Teach us to search, and find, and understand Only the calm may husband it to bear.

\section{[3]}


If know thy cold-lipped sages what they tell, And thou mad'st enmity between thy breed, Thy man and woman, then thy truth we need To know thy purpose, for we know full well Thou hadst a purpose, if on us befell What to our blind eyes seemeth to impede Thy all-embracing love, and but to lead Thy children from thee, who would fain rebel. Behind thy smiling brow and tranquil lip

Can there be bitterness to us, thine own? Why didst thou make the two thou didst ordain

To be as one, go each his way alone, Shivering in isolation, fellowship

Wounded and sundered 'neath the flesh-linked chain? 


\section{V}

We think our travail was not all in vain,

We think we have not lived for naught the years,

We think our anguish but the well of tears

That quench the flesh-fires, falling like a rain

Upon the thirsty spirit. $\mathrm{O}$ we gain,

We know we profit when thy prod appears,

We know he leaves the brute behind that hears

The still, small voices of the soul in pain.

If we not yet are large enough to kiss

The stone we dashed the foot upon, or bless

The glory that was given us to bear

So broad a burden; if the scar yet there,

And we forget not, we the wound hold less

Than pride for faith that pointed the abyss. 


\section{VI}

We think at last we read aright one law And know why thou didst lay the pain between Thy man and woman child, for thou hadst seen Thy first plan held for those to come, a flaw. Eternal Parent, thou wouldst fain withdraw From parentage all blemish and make clean Thy fathers and thy mothers that demean The race through overleaping self, and awe Thy children into guardians ripened, sage, That still the small self, serving the large whole;

That double-mothered shall the offspring wage

A war more perfect with the unselfed soul.

$O$ divine Mother, let thy light assuage Thy blinded children groping for thy goal! 


\section{VII}

We think thou madest her to be his care

Until thy man thou didst a mother make. We think thou mad'st her for the race's sake

To be his burden, that he learn forbear Unanswering freedom, learning service there; Until thy breaker had unlearned to break And learned to build, to follow in her wake That left the primal blood-print in the lair. And her thou gavest of thy mother-gift 'To bear, to build, to love for sake of love, Thou gavest patience place until the cloud Of jungle laws spread o'er thy children bowed Within thy forest crucible, shall lift, And show a later law behind, above. 


\section{VIII}

We think thou madest her his care to be Till thou thy father madest mother-wise, Till learned thy wild one from her quiet eyes To cherish peace with those that wider see Than first desire, until as devotee He learned from her slow fingers to devise In patience, building, to make sacrifice, Himself the altar where himself shall free The race of his inherited bequest, Losing the hot blood of belligerents, The raw destroyers in his thews to mould In her upbuilding essence, where, caressed, The altruistic bosom shall enfold The rampant one in her munificence. 


\section{IX}

We think we read aright one law of thine And on the upward march of us, thine own, We learn thou thrustest back him that alone Feedeth upon his heart; that thou thy sign Givest one step the more to come divine Unto thy large heart that move the stone From out another's footway, that enthrone The good of many on the sybarite-shrine. See we the mother of thy caravan Leading earth's children 'neath the white-faced moon

Whither we know not; on her bosom's span Civilization, with maternal croon Lulls her undisciplined, the maddened clan. Mad ego, war, destruction, spent triune. 


\section{$\mathbf{X}$}

Now is thy man into a mother made,

Now riotings of self doomed on thy earth,

Now may thy children sit in merrier mirth

And small content, and friendship's calm invade

New territory. Thou art not afraid

To test thy doubled parentage, new birth

Of double freedom, single strength given girth

In that thou leadest this thy last crusade.

As into mother madest thou thy man

So take thy woman in thy larger home

And make of her a patriot in the world.

$O$ fearless thou, that since thy day began

Dar'dst set thy foot through dark new way to roam

When progress went before with flag unfurled! 


\section{XI}

It may be that thy best alone link on Thy endless chain of better linked with best, And they that fit the baldric of thy test Given thy reward of wider environ.

We know that since thy early days now gone Thy victors left their own the earned bequest Of cunning voices murmuring in the breast Of forest wisdom learned in bitter yon. But forward steps a wider ambit win, And every ambit wins a new-writ law;

No more wood voices guide thy victors' shape Though yet thy many read by tooth and claw; And they that fit the baldric of the apeBut hush! the soul is quickening within. 


\section{XII}

We cannot fathom all thy mysteries

Nor see thy wisdom through thy own wide eyes; Though we may grant that in thy day that lies Far, far behind us, what this day decrees Born of the jungle, then was constancy Unto thy will. But salutations rise Fresh for each coming, and new sanction cries From out transfiguration's seething seas. We cannot fathom all thy secret wit But we may see that in our ripened hour, Shorn of the strength that proved thy forestfit,

That now thy fit have earned a richer dower, They that are worthless in the battle-pit May be thy worthy comes the soul in power. 


\section{XIII}

Though maimed thy daughter in the glimmering dawn

When yet thy children strove beneath the weight

Of far flung mandates that reverberate From out the caverns of the throats of brawn; If it were even thy great will fell pawn

To circumstance; if chance even thee frustrate; Or if thou parriest her late hour whose state Her captor held from the wild-wood withdrawn;-

All nature changes: into green the sere;

New robes for old; fresh vesture for the worn;

June rioting to greet the ample year;

While bird and bud and hill and dale adorn

Old truths with new, so would thy girls appear Reincarnated, radiant, new-born. 


\section{XIV}

If be her flesh than his more poor and frail, If, as he mindeth her, so small her soul

Beside his large inbeing, if her goal As he proclaimeth, lieth in the pale Of his departing shadow, what avail Maketh her breath, while writeth he the scroll In wearing letters, of to-day's truth, whole And uncontested while his scribes prevail? But if she strive to pierce the cosmic page, And if she lay as balm against her pride, The rubric of late harvesting the sage Hath ever marked to point their way so wide, That late she asketh of the race her wage, It may be large that she had long to bide. 


\section{XV}

If right thy sages of the ashen brow (Forgetting truth to-day is morrow's myth) Speaking the seed that budding late, more pith Than early ripened, they do but avow His body higher; yet her ghost thy bow Likewise to his. Perchance ' $t$ were but the frith Of circumstance that swept her word forthwith On earlier rock to sparkle, ere it plough Through quiet valley. (Who hath asked of them How weigh the mind and measure thought and trace

Inbeing's course on stimulation's wing?) May she not, too, find in their law a gem, Avowing hers-that in the cosmic race Waketh the last-the greater strength to bring? 


\section{XVI}

As whistling winter pipes his winds that leap From roof to roof within the sober town, That flute the hollow flageolet's renown And call derisively from spires steep,

As autumn leaves that herd like shivering sheep,

Are torn asunder hither, thither, blown: So may each little word we flaunt be thrown Idle and barren in oblivion's heap. Or when, as children, to their wiser run, Whom dandelion's shock of yellow hair A young sun seemeth, born in garden plot, The jocund lip doth jest the simple one, Or indignation turn an outraged stare. Spare thou the rod, O Mother-he will not. 


\section{XVII}

It may be some day we shall lose our dower, All hope departing like the yesteryear, Gone and forgotten like the vanished tear Some young eye dropped upon some long lost hour,

Fallen to dust with every radiant flower That made the summer unto thee so dear, Even as the snows of winter disappear

Or dews that threw the morn an opaled shower. Our hopes like birds let loose from prison bars Fling winged and warbled incense far, as yon Night's far-flung branches, efflorescent stars. And shall our once-proud birds come home again

With broken wings to soar no more? Till then Wing on, brave birds of hope, wing on! wing on! 


\section{XVIII}

If this nor jest, nor hope, but truth, some morn, I know the comfort dreamed will fade away And on thy cheek a weary lip will lay: Yet a new sorrow have I this day borne;If needs thy law be writ with bitter thorn, If of thy two thou must the one betray, If one must follow in the shadow gray, Then choose thou me again-'t were idly sworn-

Thou mad'st us other. Yet what grief if he$\mathrm{He}$ is my son, he is my friend, as thine; Spare both, make thou new covenant with me, Our woman-child hath half this heart of mine; And none would choose the shadow; give thy sign;

Make these thy two both tender and both free! 


\section{XIX}

And hear, $O$ mother of maternity,

A new truth hurled from thy rebellious child:

Give me the little one, yea, reconciled

Mad'st thou thy mother all eternity

To bring thy men and women forth to see

The splendours of thy breast, to hear the wild

Brave "din 'twixt two long silences," exiled

For one brief hour from dark tranquillity.

But know thy child hath culled a little grain

Of wisdom ripening for who understands;

As April bears, to pray for harvest lands,

On every leaf a rosary of rain,

So life and learning with their tear-drenched hands

Lay on my cheek the rosary of pain. 


\section{$\mathrm{Xx}$}

I stand as one. Now shall not anything Nor any other be for me the whole of breathing and of being. The dulled soul Hath need of sustenance and cherishing

Like as the heart. Daughter and son shall cling

In these warm arms the while I pay the toll To tender need; but ripened, I enroll

Only the measured in my gathering.

The one is thine. 'Neath tranquil starry glow

May each thy children lifting up his face,

Find his given nook, and falling into place, With steadfast footing join the ranks that go To meet the first, await the last, and be In cosmic dust lost everlastingly. 


\section{XXI}

In all thy children doth thy love impart

A tender homage to thy motherhood,

In all thou madest that is wise and good

It is thy motherhood keeps warm the heart.

Dear mother of us all, that mother art

In wisest wish, that as thy children stood

Before the beckoning hands of would and should

(Sweet wooing would!) they strike the wish athwart,

Embrace the truth, thine only counselorMay even thy mothers, motherhood to face, Know that in simple goodness there is grace For greater; see in calmer mother-lore That each alone, as one, takes highest place; See high thy mother; see thy woman more. 


\section{XXII}

Yea I am I. And as myself, as one,

I meet as ne'er I met before the strife

'Twixt love and bone and blood. $\mathrm{O}$ teach me, life!

And bear me in thy bosom, as a nun

Beareth the heavenly Bridegroom! 0 warm sun,

Smile thou on my cold qualm! Thy drum and fife,

My soul, wake to the battle! As the leaf

Trembles in autumn, tremble thou, tremble on! Hence! ye that conquered by your false alarms!

All ye defeats I meet ye once again! And when that once I lost I reattain, Or that I never had I do enclose,

O then, Great Universe, stretch forth thine arms

And gather me to rest in thy repose! 


\section{XXIII}

I will anoint my spirit with thine own, $O$ thou Great Universe that holdest me! Make bold mine eye to bear the gaze of thee, Make bold mine eye to see me all alone! Lift up my blood, rekindle thou my bone, Open thy flood-gates, O my heart, and see Victor and vanquished in the fire to be Gathered in ashes and in seed resown! How excellent the strife that is within; How beautiful the truth thou would'st upraise;

How fair the fallen honour to win o'er; How good the peace found after many days! Shall not thy wrath sustain thee and restore? Peace, peace, be still, my soul. I enter in. 


\section{XXIV}

Mother of mine, when I am weary see

How even as thou art, is thy flesh and bone,

How even as thou art, am I all alone,

How even as thou, merged in mine own decree.

Kithless apart, yet will I ever be

Kin unto all; like every seed that sown

One with the hand that sows it. $\mathrm{O}$ mine own

Fold me again quiescent unto thee!

When all thy mysteries mock me no more,

When back I gave thee all that mine to give,

When drainèd dry I need no longer live

And I, returning, seek thy gracious breast,

Then offer me oblivion as of yore

And let me find peace in thy unrest. 
PART II 


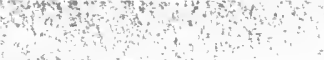




\section{XXV}

Consont and comrade, if you will, my friend, Of all that lies between us to be told, Mark here the poorer scribe whose labour scrolled

The ruder word to serve some singer's end. Some day a singing one shall music lend And to this theme of discords manifold Open her lips and into music mould The dissonances poorer skill attend. Hers be a subtler tongue; a better brain; A deeper passion, reined; and higher art To bare each nuance of a restless pain. Here but the elemental word, the part By which the broad sketch, obvious, may gain A closer reading of our two-fold heart. 


\section{XXVI}

O for a poet, for a woman's toll

To this high poinance leaping from its thrall!

$O$ that her tongue were bitterer than gall!

$O$ that her bitterness were aureole

Upon the brow of her that not the whole Forgets in hers, the half! So keep for all

Her large heart pure and undefiled to call

The thousand passions slumbering in her soul!

Lend her thy wrath, O Job! David, thy song!

Open her lips and let her heart pour forth

The wrong heaped up five thousand years and more-

If so her heart be pure and undefiled

And in her spirit that of all the earth

And in her love the love of all mankind! 


\section{XXVII}

Kinsman and comrade, mine the ages through,

I fain would find you in my hour of need, And yet the heart of me warns me take heed:

This friend, he will not lift his hand for you. It is not often that my heart withdrew Love's loyalty from love and lovers' creed; Rather love wrongs me that his favours plead: Yours all I have, and am, and hope, and do.

$O$ you that are so strong and free and wise, Is there no love unasking, faith divine Sprung from an ancient anguish of the brain? What shall it profit me that much $I$ gain And lose the love to share in grace: the sign For consummation, for uncovered eyes? 


\section{XXVIII}

I know that I must find my light within And be myself my faith, my hope, my guide;

I know that I must make me purified

Of all consent by any aid to win

That comes not from myself. I would begin

To sow in me the passion and the pride

For wisdom, beauty, truth, and learning wide As that stern freedom that shall rein me in.

But you that are so strong and free and wise:

If not the spirit leaps with mind to be

Grown beautiful in magnanimity;-

Turn a deaf ear again, darken my eyes,

Offer no fruit from bare, polluted Tree,

Nor any wisdom that is only wise. 


\section{$\operatorname{XXIX}$}

I would that I might never learn withhold A hand to lift a veil from one dark brow; Yet $I$ rejoice that all unsuccored now I would the vapours from my eyes unfold.

A want to want no aid, alone to mould My own transfiguration, springs to vow Labouring allegiance; but that I endow My tender ones with cheer, one plea were told :-

Mock me no more. Even I would see the light Swung from the towers of truth by seer and sage.

I ask no nearer lamp to pierce the dim Of those that groping go with willing limb; But would no hand-flung stones with earth's requite

The stumbling follower's earliest pilgrimage.

\section{[31 ]}




\section{$\mathrm{XXX}$}

'Tis all $\mathrm{I}$ ask. Yet $\mathrm{O}$ beloved friend, When I bethink me ' $t$ was a race we ran, We two, a brother, and a sister wan, To find the radiance in a rainbow's end; Had mine but been the swifter foot to bend, Did no wind billows in my raiment fan To swerve me backward from the far divan Awarding judgments where the glories blend:I know my step had tarried to your own And wilful faltered that we keep apace, And had the breezes me yet onward blown, And spurred my foot to take the forward place,

I know that I had sighed to go alone And back to you had turned a wistful face. 


\section{$\mathrm{XXXI}$}

If it were poor to tarry, $\sin$ to fall, Then were it poor and were it $\sin$ to grieve; But were it love that bade a comrade cleave, To lend his hand and heart to lean a wall; And since love be not heritage for all But the last gift the born of earth achieve; Then who shall say it poor, a friend to leave, Or sin, to linger loyal in her call? Yet ' $t$ were not given to falter or remain; But it were given to harbour manifest A little thought like low memorial pain Stirring within to smooth its troubled nest; That sighed the friend lost in abundant gain Had shared the sweetness of a bittered rest. 


\section{$\mathrm{XXXII}$}

If it be so that I am weak and frail

Would you not then hold out your hand to me,

Strive teach me share your higher ecstasy

At earth-want lost, and found a holy grail?.

If it be so that I am wan and pale

For outer law, not for the in-decree

Would you not then yet more my bondage see, And seeing, stoop with largess to avail?

(And let me whisper: were it so that you

Had made, or helped to make, my bonds, then I

Have title to your effort, and your proof

Of higher caste that throws a wider eye

Than its own shadow.) But I only sue:

Your travesty be fair, in fair behoof. 


\section{XXXIII}

If once my feet a wider way have trod, If once a wider wold my eyes have seen, Perchance my eager hands will pause to glean And reap a golden grain from out the sod; And are my feet too poor for rough roads shod, My eyes too blind for splendour of noon's sheen, My listless hands the harvest waive, serene, If empty-armed I backward, homeward plod; Yet who shall frown that I essayed to goWho'd stand, no poorer than I turned away, Again at the old doorway (did I know From bitter parting that but one path lay For woman's footsteps: where the embers throw Their shadow phantoms on the hearthstone gray)? 


\section{XXXIV}

Yet it may be that I shall not return

As $I$ departed, bringing in despair

Profound that $I$ an untrue altar there

Had builded where the hearth-fires subtly burn.

It may be that I carry with me stern

And sad a reckoning to the fire-side fair

That warmed the flesh in its rose-shadowed snare

And held the heart a captive, there to spurn The murmuring voices of the mind and soul. And though your soul closed mine the innerest door

And bade me serve the body, satisfied,

I shall not rest me ever anymore

Till our two spirits, searching side by side,

Drift, singing in accord, across the Goal. 


\section{XXXV}

My baby dear, the white moon in his bower That watches night-long over you and me, Is not so old as that long memory That guards the tender ere in full they flower. My baby dear, if from some unknown power The mother that so loves you heard a plea: A mother in a wider world to be, To mother all men in a coming hour:Somewhere in God's inviolable plan we know Your innocent sweet head's least golden hair Is numbered and remembered and held dear; If came your mother wise, as loving, here, Nor yet the smallest were forgotten there, Love's vigilers, baby, drew but closer so. 


\section{XXXVI}

I count the years my mothers watched the fire,

I search the past they gave into your hand. But $\mathrm{O}$, dear friend, I do not understandI speak with heart too grave and full, for ireWhat have you done with her, who as empire Gave you her life to sway with waft of wand?

I am not comforted that your command Answered her want, or nurmured her desire. Though many another looks content behind, Feeling no tumult rising to the throat, Reading in calm the page of womankind, There are the all-forgiving, that the debt Proud eyes to honoured filiation note Must still remember, cannot yet forget. 


\section{XXXVII}

I am not comforted when I behold The pages of the mothers of the race, I am not comforted that their one place Is in man's arms, when mindful how of old Their womanhood was cast into the mould Of his desire. I see not his embrace Winning from both, the wingèd angel trace Too near clasp crushes, to unfan, unfold. I am not comforted that he alone

Is wise and pure and large and calm to speak For all the race. I deem the woman's own Voice from the woman-half, though trembling, weak,

In new-tried effort, folds in undertone A balm for world-wounds weeping through the bleak. 


\section{XXXVIII}

You wrote my page. Go read the chronicle, Call me ungenerous, if you will, and cold, And tell me that it is not mine to mould Words that disquiet in my lips instil. But I am not so small and mean and ill Of grace that I the world-work not behold Wrought all by you. (I, looking from my wold Nor saw nor succored) and verily-I thrill! You wrote my page. Go read the document, And think me cold of comfort if you will; But I can praise too, and the wonder lies Wide on my lips and deep within my eyes; If it is mine to make arbitrament: Brother, your work is grand, magnificent! 


\section{XXXIX}

A ploughman lone you loomed the bleak dawn through,

But glad against the harvest moon you stand. You rose the morning for the arid land To sow the seed of all we know and knew; And with the sweated brow in evening dew Poured forth fulfillment from laborious hand; The grain-bag scattered in the desert sandBehold! The beautiful, the good, the true! (Bar woman, sold to aid) all salient gain In granary or reliquary yours, And even the arrogant stars in timeless tours Come when you call them with their retinue. The while I grant all this so free, so fain, Ah yes, I grant it, I am jealous too. 


\section{XL}

I would that I might say: This is the least; Or this the "most unkindest cut of all;" Yet it is one of many steeped in gall:

My life in you, from Life I pass unmissed. Unknown, unbidden, I sit not to the feast But with my ear pressed to the outer wall I hear the higher invocation call To saint and sage and babe and bard and priest.

This wounds my honour of a verity:

That I not share the glory of mankind

That reined the heart it reared, and builded mind,

And gave the soul the highest sovereignty. I would the women coming after me New crowns of bay, with old sweet myrtle twined. 


\section{XLI}

I love the huge sphynx of the desert more Than pretty carving on a cherry stone.

I love wild Triton when the horn is blown That sends the flying columns in uproar:

Column following column, his artillery pour, Till the white cavalcades ride on alone Foaming at mouth, and mad with monotone The hoofs of ocean thunder on the shore!

I love a woman's tender sacrament, But ne'er so sacrificial love goes cheap.

I love a woman grand, belligerent, Lifts one his voice to lay her truth asleep. $O$ soul, in some high passion torn and spent, How art thou radiant in thy discontent! 


\section{XLII}

There is a loyalty more true by far Than other loyalties however dear, There is an honour and a faith so near That may the love-bond never more debar; And mate and brother and the friends that are So loved of woman, since the yesteryear And till last morrow mornings do appear Not in first purple, but in cinnebar, A royal red, and royal purple hold For constancy to self and to the race;

For woman brings remembrance that the mould Of motherhood is womanhood's to trace. Now first for self, then for man manifold, Loyal and royal blooms the rose of grace. 


\section{XLIII}

I love not her that eager drinks the wine

Which flattery and condescension quaff,

That drains the last drop from the full caraffe Of those who with the younger poets dine;

And drinking, looks not through the crystalline,

Nor hears within the bubble subtle laugh, Nor sces the sparkle as truth's epitaph,

Dazed with the fragrance of the honeyed vine.

I love not her that loves not womanhood

Too deep to love a shallow chivalry,

I love not her that never haughty stood

(In some young girl-time, ere serenity)

And vowed a day of reckoning were good With the sweet word that hides its tyranny, 


\section{XLIV}

There is a hope we bear within us yet, That are the praises of her lovers true:

Our lady lovely as the jasmine hue, Our lady tender as a canzonet, Is our fair lady like the violet, In modest fragrance, like the tranquil dew So bright, so chaste, and like unwithering yew Erect and constant, and of finest fret:As naught corrupts the law of dew or flower (As ' $t$ were the fragrance in the lily died For night wind, noon sun, or the drummer shower)

So woman-fragrance, were it given to bide In shelter only, came no regal dower Commanding homage and unbending pride. 


\section{XLV}

How richer are the spices of the bud

That swings its censer on the wind and rain!

What profiteth a tenderness that slain

And sullied lies in April's earliest flood?

Did ever primrose rouge with flaunting rudd?

In busy market-stall near poppy lain,

With thyme and parsley on a huckster's wain,

What purple violet forgets her blood?

Where joy and beauty spring from thriving root,

They perish only in the flagrant storm;

Only the weak flower broken lies ere yet

It spent its little day through wind and wet.

Mean you the woman grace is but a shoot

Each rude wind may bedraggle and transform? 


\section{XLVI}

And what of gardens bared and unconfined Where wanton storms at sweet will havoc fling?

What of a garden where the tares upspring Till flower and fruit for sun and air had pined? What of a gardener that no bower shrined For frost-fall's vintage-does he hope to swing

A pregnant sickle, and the vintage bring

Untasting of the bitter of the wind?

What of a fruit that mellowed in an air

Polluted so no flower could breathe and live?

What if the gardener were to come aware

That what is choice and fine (nor fugitive)

Might there a place find where such graces bear The purpling clusters it is theirs to give? 


\section{XLVII}

I stand no more in that young haughty way (Youth is so haughty) and with cold proud eyes

Turn from a hand that at my service lies: "I need not you who come at this late day." No more so young as I was yesterday, I would not scorn a word that may be wise Nor spurn a hand that with my own unties One smallest knot of those that me waylay. And you that went so long in world so wide, You that have sat so long at wisdom's feet, May know we too have lived that lay aside The vanity the dearer needs must cheat, May know we too have learned that would abide By wells of wisdom, though we humble eat. 


\section{XLVIII}

There is not anything that life can give

To him that has not given his life in turn, With gall and wormwood we the soul do earn, And who forgave not is not ripe to live, Who knew no anguish is calm's fugitive, Who never drank from out the bitter urn, Who on no altar laid his flesh to burn;Ne'er saw his spirit the cold ashes leave And hold communion with the watching Whole, Not on his cheek the breath of stars left trace, Not him low voices call from pole to pole, Ne'er heard he footsteps of the eerie race That pierce upon the brow the aureole, Nor with his God stood ever face to face. 


\section{XLIX}

Like as our brothers of the green we bow To friend, to foe, to wind and storm and sleet. Like as our brothers ' $t$ is the bread we eat, The way we won our bread, the reckoning how, That made us what we were, what we are now, (And what we will be): from the flock's low bleat

An ancient nation went to tend the wheat, A race of shepherds husbanding the plow Till followers of Christ denounced His kin, Forcing the Israelite upon the mart, (Whose tie diluted with the origin Of trade Phoenician merchant-men gave start) Till shepherd, plowman, merchant-man, merge in A markèd people, bred by bread apart. 
You are my bread, my roof, my wherewithal. So have you gathered me into your hand And held me in the hollow, to expand, Or crush, or fondle, worship, or let fall. The mother of the green is not so small Before her consort helpless thus to stand, That serves her nurslings', and her own, demand,

And leaps, a colleague, to each forest call. I will not eat your bread, I will be proud; The loaf of life my eager hands would share; My long served lips taste of a self-served wine; The bed I rest in my own hands prepare; And with the outer eye close-shuttered, bowed, Kneel for my sanction at the inner shrine. 
How often I have turned from you away, I knew not why, perhaps, or knew too well;

A wall of stone upreared before, or fell

In crumbling ashes, mingling clay with clay.

I have not seldom turned my eyes astray

(From whence so fondly they once looked to dwell)

Barren of hope-for what? Ah, who shall tell-

We only knew we faced a colder day.

There loomed the wall between us, dust or stone,

Between us twain eclipsed to mutual one; But when my eyes look in my baby's own (As ere again were sundered we in two)

Where is the hardened calmness-orizon! Sce how my eyes are wet with love for you. 


\section{LII}

No, ' $t$ is not true. That earlier hour is past I hear but one voice, make but one demand, When of God's all, ' $t$ is mine to understand Only fair love, while all else in the vast Unfathomable infinitude he cast Before me leaves me cold. Some other hand Than fair love's beckons me, some larger land Than sweet Arcadia holds me home at last. No, ' $t$ is not true. It is not true that love (Love that so fair is) is my only lord To hold me ever on his breast impearled. There is a higher power my lord above, Than love's, I hear the richer, fuller, chord That calls me live for God and all the world! 


\section{LIII}

We live alone. Love has not any power

To tread the sanctuaries of the soul;

Yea, hand in hand may two together stroll

Into the hush of the illumined hour;

But each in his own hand must seize his dower

In that brief moment when the gray mists roll

From his dark eye-lids, and the groped-for goal

Glimmers a halo like a star-dipped tower.

There lies within a crypt so sacred, own,

The nearest may not enter in so far,

There is no handclasp underneath the stone,

No friend to share the mildew and the rust,

Nor any love to call an avatar,

And one by one we sink into the dust. 


\section{LIV}

The wisest of all mothers taught us this:

To eat and drink and merry be and die; And we the legions of the earth go by Dumbly contented. (Like the chrysalis Not ours to dream of metamorphosis.) Thus to the grave we go by paths that lie Before the threshold of the cradled eye, Crowding the warm way to the cold abyss. But some there be that leave the peopled din To find a light for those that bold would go; Humbly for one small fagot searching, lo! They find the gate and sound the clarion Before the House of God. We follow in. These are the bitter-steeped that lead us on. 


\section{LV:}

This were the spirit one would fain foretell, As were a stalwart stooping as her guide: Lady, we two may labour side by side Nor yet in æons half our goal compel. He only lives, who quickens to the spell Of some large spirit, though he swept no stride Beyond the cold stones that the cloistered hide; Then leave the hearth or linger, only well Let you your love magnanimous so be No four walls may constrain it. Willingly Bend to the cosmic love. The thorn, neath bay,

Crowned in the wise wide world, is not forgot, Though laurel arches bridge the winner's way And regal cypress grenadier the spot. 


\section{LVI}

Sometimes I sought the light-house steep and stark

That stood knee-deep upon the sands o' sea;

When spring and hope swept, urging, over me To drive me from my corner in the dark.

The child beneath' the cloak, forth with the lark

I sought the light for each at dusk swung free; But ne'er a goodman told where it might be; The student, scholar, smiled upon my cark. At twilight loomed the tower, and with slow pace

I climbed the winding stairway steep and high, Till at the keeper's door-a hermitage

That grudged me entrance-at the shutter, I, A humble acolyte in pilgrimage, Searched for a sign the noble, chastened face. 


\section{LVII}

"The sage is honour-bound," low, courage purled;

"Others may scoff, or stand indifferently,

But wisdom sought, when hopeless, most must be A cause for tears." Thus hope me inward whirled.

"The blazing pennants beauty, truth, unfurled Over all earth, that all the race might see-" "Lady, forgive me, but your place—" quoth he, "You are not of, but for, the race, the world!" I touched his books, saw badges honour won. "If shared by woman have they still their worth?

But mothers holy-crowned by all on earth-" Spread for my way the cloak of chivalry; But no light streamed the unrailed stairway down,

And ere my feet untangled clicked a key. 


\section{LVIII}

If on that new-found shore I walk the strand As those who would forget, yet straightway flee To hear the dull despair of desolate sea, To scan a deep that laves no fatherland; If there I find upon the dunes, the sand, The pink ear ocean lends to memory, The waves' pale lips that with eternity Murmur a mother-tongue they understand:Unwelcomed foreigner, no lip, no ear Can comfort me or hear my ancient grief, Till ear to ear old recollections wake. But when the lips the primal past forsake: The valorous brine beats up the sunlit reef; Laughing, the ripples trip it o'er the mere! 


\section{LIX}

As little children let their lanterns fly, My light I fain would lift as in a bowl, And I, a world-child, from my hands to roll Send forth a white moon swimming in the sky; Or, striding through the shuffling clouds that lie,

A pilot-star that beats the azurn shoal.

Alas! my light is but as living coal That burning hearts enkindle or they die. And yet, what though my wick still fail the night?

My tinselled crystal globe as bold as youth Fall shattered, wide-blown by its own hot aim?

Or if there be not any fire in truth, I, who in darkness learn to yearn for light, May as the touchwood but await the flame. 


\section{LX}

And though in moments I am overborne And would be gathered in a perfect rest, And safe and sworn lie, as upon his breast The frail white flower of the Finsteraarhorn; First I must climb, from gorge and spume come torn,

And should I rise up from behind the west, How proud the eyelids lift the tears tell best, When from the Furka I behold the morn! If ' $t$ were I watched with him the breaking dawn,

Like Furka's or like Finsteraar's high-born flower,

The last doubt in the reeling mist far gone, Then, safe and sworn, with each forever won, I shall rise up caressed and proud in power, When thus with Furka, I salute the sun! 


\section{LXI}

The hour has come. I will arise and go.

I will away to take my place with thine, That knelt so long before the olden shrine Nor stayed my sons make other women's woe.

I will not in repose prevail, but lo!

I will anoint me with the words divine "Labour laborious." Labouring for mine I will not stay, I will arise and go.

I will not rest until I try anew

In ways untried before that may avail, To build my shrine so beautiful, so true, Out in the noble world where lingers he, The call to worship holds within the pale Even those that now from far give praise to me. 


\section{LXII}

Your squadrons, all your ships of state and war Hold more the prize than cruise or unsmirched flag.

Lusts of dominion with the pirate rag Riddled and black, sweep up the harbour shore! We, till full skilled, would learn at galley, oarWe, on each float that splinters on a crag, We, who give life, that which you take, to drag Downward, our flesh and bone to rise no more. In the Armadas of a coming year, Life at the prow hunts the wide seas for death. With mankind's manlier proof of manliness, These ruptures small, in small spots, drink the less

Prime's priceless blood. Women's cost to give men breath

Is high to feed the worms or deck a bier. 


\section{LXIII}

Stand back! It is not yours to shape my destiny.

When have I circled scheme and scope for you? If God that made you vain made measured too-

One brief hour past kings scoffed your commoner's plea

And pointed nature's law and God's decree Till long denial, breeding doubt, withdrew.

Is, then, the spirit's best dream parvenue That freedom, inborn, severs memory?

It is not yours to shape my circumstance;

It is not mine to charter grace to you;

Where humanhood is sound we know the clue:

"This is not given to give." We are but thieves Who yield as ours, as boon, the inner utterance

That each, nor alms, from higher power receives. 


\section{LXIV}

Go see your blood-black hand-print in the face of mankind's mother where you struck heryou.

Mother's or maid's, the sullied scroll read through:

A harlot waiting in the market place! And still your learnèd metes his mother grace: Mother and harlot: one; and if as two, Lower the mother-there no "I" the clue To what makes mankind: mind: the man: the race!

When harlot, mother: one-in even one view To leave, be other, were the onliest, best:

This sage, this suckling on life's ripened breast, Teach haste becomes not cosmic-sweeping eyes. Aye, wait an humble æon yet or two, But give me back my ego else I rise! 


\section{LXV}

Mite! Wise in nature's law and God's decree,

Know life was lived ere you, and from the dust

Life's mothering reared you-yea, life's mothering trust,

Mothering and love-one immortality!

Your sire a lowliest cell maternity

Chose that a soul therein might yet be thrust, Culled till each son a better sire-august!Culled till her men stood mightier than she! Made strong, you cowed her, chose—for fleshnor saw

Earth still holds secrets hidden in their prime, That purer feet shall follow God with awe, And riper lips than yours read rule sublime. Ah, wait till God's decree and nature's law Slip wiser from the chrysalis of time! 


\section{LXVI}

My heart has found no grace. Even Arcady: "Drain not love's cup, for all its whispering wine."

And well I know the oracle divine

Bids me go hence that I come near to thee;

Bids me, if far, thou comest closer me;

Murmuring, and be the tryst 'neath palm or pine-

Of all the laws of God, but one makes mine:

Love, life, they tarry everlastingly.

O love, we read thy sibylline lip for sign:

"Aye, love ye must! But much beside may be."

We cannot lose thee. With conspiracy

Thy moorva fast about us thou dost twine;

And in thy juvenescence we are thine,

Mortal, thy bridge to immortality. 

University of California

SOUTHERN REGIONAL LIBRARY FACILITY

405 Hilgard Avenue, Los Angeles, CA 90024-1388

Return this material to the library from which it was borrowed. 
3541 Urban -

U705s Sons of God and daughters

of men

PS

3541

U705s

A $001247798 \quad 0$

UC SOUTHERN REGIONAL LIBRARY FACILITY

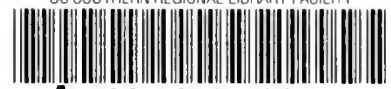




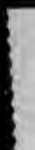

